\title{
SUCCESSFUL STUDENTS IN AN OPEN AND DISTANCE LEARNING
} SYSTEM

\author{
Dr. Kristanti Ambar PUSPITASARI \\ FKIP, Universitas Terbuka \\ Tangerang Selatan, Indonesia \\ Boedhi OETOYO \\ FHISIP, Universitas Terbuka \\ Tangerang Selatan, Indonesia
}

\section{ABSTRACT}

Learning in a higher education institution that applies an open and distance learning system requires the students to study as independent learners. This research is a survey research with the purpose of exploring the characteristics, habits and learning motivation of high-achiever students or those who obtained a high level of Grade Point Average (GPA). The sample used in this study was Universitas Terbuka (UT) students of Non Elementary Education Programs who had completed at least four semesters and had obtained a GPA of 2.50 or higher. This study discovered that the high-achiever students were younger students of the average age of $\mathbf{2 9}$ years. Most of these higher achiever students were highly motivated to study and were studying at UT to support their career development. They usually studied 3-4 hours/for each course each day. Interviews showed that students generally did the self-assessment tests and they regularly attended the tutorials. The time of study $(p=.001)$ and methods of study $(p=.01)$ recorded in this study have the potential to contribute to the students' GPA.

Keywords: Students' characteristics, learning habits, student success, distance education, ODL, Universitas Terbuka.

\section{INTRODUCTION}

Students of the Open and Distance Learning (ODL) system can be divided into two groups (Wilson, 1997), namely adult students and young high-school fresh graduate students. The adult students generally have left school for several years. Although they have strong motivation to continue their studies, this group of students may not have sufficient selfconfidence to complete their study in an ODL system. On the other hand, the group of younger students have probably just graduated from the structured learning system in a regular classroom. These students may not have sufficient self-confidence either or they may not have enough skills to manage their own learning activities in the ODL system. Lack of confidence to be successful in an ODL system may influence their decision as to whether they will persist in their studies at the ODL institution or not. Research found that motivation influenced ODL students to persist in the system (Aragon \& Johnson, 2008; Holder, 2007; Roblyer, 1999). Among motivational aspects, self-efficacy is considered the best predictor of the success in a blended learning system (Lynch \& Dembo, 2004). Selfefficacy is defined as one's strong belief in oneself that one has the competency to do a certain task (Schunk, 1991). A person who has high self-efficacy is happy to do challenging tasks. On the contrary, one who has low self-efficacy may choose an easy task to do, thus avoiding challenging work. The blended learning system is a system that combines the typical face-to-face learning system and online learning using computer and information technology. 
As well, successful ODL students are characterized as those who are able to manage their time well, have good learning habits, and study regularly (Holder, 2007). However, poor time management was also reported to cause students withdrawal from ODL (Aragon \& Johnson, 2008; Doherty, 2006; McGivney, 2004; Roblyer, 1999). As ODL students usually are workers, they need more time and greater commitment to complete their studies (Doherty, 2006; Fozdar, et al, 2006; Roblyer, 1999). Students who are unable to manage their study time and tend to procrastinate their learning activities (Doherty, 2006) are likely to be unsuccessful in their studies. Since ODL students often have to study alone, they themselves may have to determine how many hours a day need to be reserved for studying (McGiveney, 2004). According to McGiveney, not attending classes regularly can cause ODL students not to study regularly. Without a routine or fixed study schedule, they tend to attend to other tasks such as office-related jobs, socializing or completing other chores. Postponing studying and completing assignments may cause students to start studying only when examinations are approaching.

Learning in an open and distance higher education system requires the students to adjust their learning habits. This is the case for students at Universitas Terbuka (UT), which applies an ODL system. Indonesians are very accustomed to listening to the teacher's explanations at school, from kindergarten and elementary school up to high school. Thus, they must change their learning habits and methods when they are studying at UT. These students must have the skills of independent learning. Independent learning means a process of learning that is directed by the students' own initiative, which can be done individually or in a study group.

Despite the obstacles ODL students face, there were many students who successfully completed their studies at the UT. This study focused on exploring the characteristics of successful students in the ODL system. By considering these characteristics, the institution could plan the best strategy to increase the student persistence rate in the ODL system.

By studying the characteristics of the students who succeeded in achieving a high Grade Point Average (GPA) in spite of having obstacles when studying at a distance, the university can design appropriate support services to assist students who are less successful based on the motivating factors and learning habits of the successful students. In this research, successful students are defined as those who, in 2014, had been studying at the UT for at least four semesters and were able to achieve a GPA of 2.50 out of 4.00 or higher.

Specifically, this study addressed the following research questions:

$>$ What are the characteristics of the successful students at UT?

$>$ What is the motivation of the successful students at UT?

$>$ What are the learning habits of the successful students at UT?

$>$ Is there any relationship between the characteristics of the successful students and their academic achievements?

$>$ Is there any relationship between student motivation and students' academic achievements?

$>\quad$ Is there any relationship between the learning habits of the successful students and their academic achievements?

\section{METHOD}

\section{Participants}

UT is the only university in Indonesia which applies ODL system. This university offers 34 programs of study that are differentiated into two major programs, which are Non Elementary Teacher Program (NETP) and Elementary Teacher Program (ETP). Students in NETP are those who attended programs of study which were not intended for elementary teachers, which consisted around $20-30 \%$ of the student body. This research involved students of NETP at the UT who had completed 4 semesters in 2014 and earned a Grade Point Average (GPA) of $\mathbf{2 . 5 0}$ or more. Students who had completed $\mathbf{4}$ semesters at UT were 
considered to be able to adjust to the ODL system. Students who earned a GPA of 2.50 were considered to be those succeeding in their study in the system. The GPA data, taken as a measure of the students' achievement, were obtained from the Students Record System (SRS), and were then divided into three categories (GPAs of 2.5-2.9; 3.0-3.5; 3.6-4.0). An email was sent to 1,217 students who had a valid email address, seeking their participation in this study.

The samples were selected from the 1217 students in all four schools of NETP at the UT (School of Economics, School of Social and Political Sciences, School of Teacher Education and School of Mathematics and Natural Sciences) who registered in the Regional Offices of the UT (ROs) in the island of Java and outside Java. Out of the 1217 students, only 116 students responded to the questionnaire attached to the email $(10 \%)$ and only $93(8 \%)$ questionnaires could be analyzed. The small number of respondents who were involved in this research was one of the weaknesses of this research. There were several reasons for the small number such as that most students did not check their emails recently and that many students were probably not willing to be involved in this survey.

\section{Data Collection and Analysis}

The data were collected using a questionnaire attached to the email sent to the selected students. The information gathered covered the following: (1) demography; the RO where students had registered; gender, age, latest education, program of study; the average number of courses taken in one semester; occupancy; (2) motivation (self-efficacy and the purpose of studying at UT); and (3) learning habits (having study schedule, time of study, hours of study in a week, and the regularity of studying). Student achievement was measured by the students' GPA obtained from the SRS.

Six students were selected out of the respondents to be interviewed. The purpose of the interview was to understand the learning habits of those who succeeded in achieving their study outcomes. The respondents who were interviewed were selected purposively from students who lived in Bogor and whose telephone numbers were recorded in the SRS.

The demographic data were analyzed using descriptive analysis and cross-tabulated with the students' GPA. Student motivation and learning habits were correlated with their GPA to investigate the relationships between student motivation and learning habits with their GPAs.

\section{FINDINGS}

Students responding to the questionnaires were from 23 out of 39 ROs all over Indonesia. $R O$ is a representative office of the UT responsible for providing services to students beginning with student recruitment to registration, tutorials and graduation. Questionnaires that could be analyzed further came from 93 respondents. The biggest number of respondents was from the capital city, Jakarta $(28 \%)$, and surrounding cities like Bogor (15\%) and Bandung (10\%).

\section{The Characteristics of the Successful Students at UT}

The data indicated that the students who were successful in learning at UT tended to be younger i.e. $<35$ years of age with the average being 29 years. Mainly, they lived in Java $(72 \%)$. However, many students from several regions outside Java also had the potential to achieve a higher GPA at the UT. 
Table 1. Students' characteristics $(n=93)$

\begin{tabular}{|c|c|c|}
\hline Characteristics & Frequency & $\%$ \\
\hline \multicolumn{3}{|l|}{ ROs } \\
\hline Java & 67 & 72.0 \\
\hline Outside Java & 26 & 28.0 \\
\hline Total & 93 & 100.0 \\
\hline \multicolumn{3}{|l|}{ Gender } \\
\hline Male & 47 & 50.5 \\
\hline Female & 46 & 49.5 \\
\hline Total & 93 & 100.0 \\
\hline \multicolumn{3}{|l|}{ Age Group } \\
\hline$<25$ years old & 34 & 36.6 \\
\hline $25-35$ years old & 39 & 41.9 \\
\hline $36-45$ years old & 19 & 20.4 \\
\hline$>45$ years old & 1 & 1.1 \\
\hline Total & 93 & 100.0 \\
\hline \multicolumn{3}{|c|}{ Educational Background } \\
\hline Senior High School & 70 & 75.3 \\
\hline Diploma & 13 & 14.0 \\
\hline Bachelor & 8 & 8.6 \\
\hline Postgraduate Study & 2 & 2.2 \\
\hline Total & 93 & 100.0 \\
\hline \multicolumn{3}{|l|}{ Occupation } \\
\hline Government Official & 12 & 12.9 \\
\hline Private & 71 & 76.3 \\
\hline Housewife & 2 & 2.2 \\
\hline Students & 2 & 2.2 \\
\hline Others & $\overline{6}$ & 6.5 \\
\hline Total & 93 & 100.0 \\
\hline \multicolumn{3}{|c|}{ Number of Courses/ Semester } \\
\hline 3-5 courses & 8 & 4.6 \\
\hline 6 courses & 23 & 24.7 \\
\hline 7 courses & 33 & 35.5 \\
\hline 8 courses & 29 & 31.2 \\
\hline Total & 93 & 100.0 \\
\hline \multicolumn{3}{|l|}{ GPA } \\
\hline$\overline{2.50}-2.99$ & 70 & 75.3 \\
\hline $3.00-3.49$ & 17 & 18.3 \\
\hline $3.50-4.00$ & 6 & 6.5 \\
\hline Total & 93 & 100.0 \\
\hline
\end{tabular}

Table 1 indicates that the majority of the respondents were high-school graduates $(75 \%)$ and almost all them were part-time students or working students $(90 \%)$. Most of them worked in the private sector while the rest worked as government officials $(13 \%)$. Generally, the students took 6-8 courses per semester. The majority of the students $(75 \%)$ earned GPAs of 2.50-2.99. Only 6\% of them obtained very high GPA scores i.e. 3.50 to 4.00.

The Motivation of the Successful Students at UT

Student motivation was represented by the variable of a strong belief in being able to complete their studies (self-efficacy) and their purpose of studying at the UT. Eighty percent $(\mathbf{8 0} \%)$ of the respondents had high self-efficacy or believed that they would be able to complete their study at the UT.

Table 2 indicates that most respondents had high self-efficacy in studying at the UT. More than half $(61 \%)$ of them stated that they had enrolled at the UT with the hope that the knowledge they would get from the UT would support their performance on the job. In addition, almost $30 \%$ of them stated that they studied at the UT in order to earn a degree. 
Table 2. Student motivation [n=93]

\begin{tabular}{lll}
\hline Learning Motivation & Frequency & $\%$ \\
\hline Self Efficacy & & \\
High & 74 & 79.6 \\
Low & 19 & 20.4 \\
\hline Total & 93 & 100.0 \\
\hline The purpose of studying at UT & & \\
To improve knowledge & 8 & 8.6 \\
$\begin{array}{l}\text { To support their performance at the } \\
\text { job }\end{array}$ & 57 & 61.3 \\
To earn a degree & 28 & 30.1 \\
\hline Total & 93 & 100.0 \\
\hline
\end{tabular}

The Learning Habits of the Successful Students at UT

The variable of learning habits investigated in this study represented the availability of a study schedule or a study plan, study time, hours of study, the regularity of study, place of study and the methods of study used. Table 3 indicates that the majority of the students did their study at night $(76 \%)$, and they usually studied at their working place $(68 \%)$.

In general, the students did not have a specific schedule for studying. However, they used any spare time to study.

"I have no regular time ... whenever I have a spare time I'll use it to study or to participate in online tutorials (OLT) ...."

Table 3. Students' learning habits [ $\mathrm{n}=93$ ]

\begin{tabular}{lll}
\hline Learning Habits & Frequency & $\%$ \\
\hline Study Time & 1 & \\
\hline Morning & 14 & 1.1 \\
Day time & 7 & 15.1 \\
Evening & 71 & 7.5 \\
Night & 93 & 76.3 \\
\hline Total & & 100.0 \\
\hline Hours of Study & 41 & \\
\hline 1-2 each day & 52 & 44.1 \\
3-4 each day & 93 & 55.9 \\
\hline Total & & 100.0 \\
\hline The Study Regularity & 28 & \\
\hline Learn every day & 51 & 30.1 \\
Learn on week-end & 14 & 54.8 \\
No regular time & 93 & 15.1 \\
\hline Total & & 100.0 \\
\hline Place of Study & 20 & \\
\hline At home & 63 & 21.5 \\
At work place & 2 & 67.7 \\
In the library & 8 & 2.2 \\
Others & 93 & 8.6 \\
\hline Total & & 100.0 \\
\hline Methods of Study & 9 & \\
\hline Take a note while learning & 4 & 9.7 \\
Make a summary after learning & 79 & 8.3 \\
Doing the exercise & 1.9 \\
Look for other learning resources & 1 & 100.0 \\
\hline Total & 93 & \\
\hline & & \\
\hline & &
\end{tabular}

"I don't have a fixed schedule to study. I am a field worker and my working schedule is very flexible, so I learn whenever I have spare time."

In relation to study duration, more than half of the respondents $(56 \%)$ stated that they studied for 3-4 hours a day for each course and the rest said that they learned 1-2 hours a 
day. About half of the respondents (55\%) stated that they studied at weekends. The findings seemed contradictory, which indicated that only one third of the respondents studied more regularly each week. In addition, considering that $68 \%$ respondents studied at the work place, it is possible that they worked during the weekends $(76 \%$ of the respondents worked in private sectors). Many of them probably studied at the work place in order to have access to the Internet to be able to access UT's online tutorials. Most of them $(85 \%)$ did the assignment when learning while only a few students made note, made a summary, or sought other learning resources when studying.

The Relationship between Students' Characteristics and Their GPA

The cross-tabulation of the students' characteristics and their GPA, did not yield any significant results. Students' age, educational background, domicile (Java versus Outside Java), and occupation did not have any correlation on the students' GPA. The average age of these successful students was 29 years with an average GPA of 2.87 .

Considering that the number of the UT's younger students is increasing from year to year, it was expected that the GPA of younger respondents might be higher. However, there was no significant correlation found between the respondents' age and their GPA $(r=.100$, $\mathrm{p}=.341)$.

Table 4.The average of students' age and GPA

\begin{tabular}{lcll}
\hline & Average & $\begin{array}{l}\text { Deviation } \\
\text { Standard }\end{array}$ & $\begin{array}{l}\text { Total } \\
\text { Number }\end{array}$ \\
\hline Age & 29.20 & 7.185 & 93 \\
GPA & 2.8732 & .28707 & 93 \\
\hline
\end{tabular}

The Relationship between the Students' Motivation and Their GPAs

Student with higher motivation to study may be expected to have a bigger effort to achieve his/her study plan. Thus, the student motivation as reflected in their belief to be able to complete study at UT was expected to contribute to the GPA. The result of the crosstab indicates that student self-efficacy or their belief in the success of studying at the UT might have some effects on the GPAs. However, no significant evidence was found (chi square $=4.956, p=.084)$. The result of the crosstab between the purpose of studying at the UT and the GPAs also yielded no significant difference $(p>.05)$.

The Relationship between the Students' Learning Habits and Their GPAs Time of study (Table 6 ) was found to have a very significant relationship with student GPA (chi square $=23.457, \mathrm{p}=.001$ ).

Table 6. The results of crosstab between time of study and students' GPA [n=93]

\begin{tabular}{|c|c|c|c|c|c|c|}
\hline \multicolumn{7}{|c|}{ GPA Group } \\
\hline Time of $\mathbf{S}$ & & & $\begin{array}{l}2.50- \\
2.99\end{array}$ & $\begin{array}{l}3.00- \\
3.49\end{array}$ & $3.50-4.00$ & Total \\
\hline Morning & $\begin{array}{l}\text { Count } \\
\text { \% within } \\
\text { Study }\end{array}$ & Time of & $\begin{array}{l}0 \\
0.0 \%\end{array}$ & $\begin{array}{l}0 \\
0.0 \%\end{array}$ & $\begin{array}{l}1 \\
100.0 \%\end{array}$ & $\begin{array}{l}1 \\
100.0 \%\end{array}$ \\
\hline $\begin{array}{l}\text { After } \\
\text { Noon }\end{array}$ & $\begin{array}{l}\text { Count } \\
\text { \% within } \\
\text { Study }\end{array}$ & Time of & $\begin{array}{l}9 \\
64.3 \%\end{array}$ & $\begin{array}{l}2 \\
14.3 \%\end{array}$ & $\begin{array}{l}3 \\
21.4 \%\end{array}$ & $\begin{array}{l}14 \\
100.0 \%\end{array}$ \\
\hline Evening & $\begin{array}{l}\text { Count } \\
\text { \% within } \\
\text { Study }\end{array}$ & Time of & $\begin{array}{l}5 \\
71.4 \%\end{array}$ & $\begin{array}{l}1 \\
14.3 \%\end{array}$ & $\begin{array}{l}1 \\
14.3 \%\end{array}$ & $\begin{array}{l}7 \\
100.0 \%\end{array}$ \\
\hline Night & $\begin{array}{l}\text { Count } \\
\text { \% within } \\
\text { Study }\end{array}$ & Time of & $\begin{array}{l}56 \\
78.9 \%\end{array}$ & $\begin{array}{l}14 \\
19.7 \%\end{array}$ & $\begin{array}{l}1 \\
1.4 \%\end{array}$ & $\begin{array}{l}71 \\
100.0 \%\end{array}$ \\
\hline Total & $\begin{array}{l}\text { Count } \\
\% \text { within } \\
\text { Study }\end{array}$ & Time of & $\begin{array}{l}70 \\
75.3 \%\end{array}$ & $\begin{array}{l}17 \\
18.3 \%\end{array}$ & $\begin{array}{l}6 \\
6.5 \%\end{array}$ & $\begin{array}{l}93 \\
100.0 \%\end{array}$ \\
\hline
\end{tabular}


Hours of study time did not have any significant relationship with the students' GPA, even though the significance value was very close to the alpha (chi square $=5.360, p=.069$ ). However, it is important to note that $31 \%$ of the students who studied 3-4 hours each day obtained a GPA of $\mathbf{3 . 0 0}$ or higher.

Table 7. The result of cross tab between hours of study time and students' GPA [n=93]

\begin{tabular}{|c|c|c|c|c|c|}
\hline \multicolumn{2}{|c|}{ Hours of Study Time } & \multirow{2}{*}{$\begin{array}{l}\text { GPA Group } \\
2.50-2.99 \\
34 \\
82.9 \%\end{array}$} & \multirow{2}{*}{$\begin{array}{l}3.00-3.49 \\
7 \\
17.1 \%\end{array}$} & \multirow{2}{*}{$\begin{array}{l}3.50-4.00 \\
0 \\
0.0 \%\end{array}$} & \multirow{2}{*}{$\begin{array}{l}\text { Total } \\
41 \\
100.0 \%\end{array}$} \\
\hline $\begin{array}{l}\text { 1-2 hours } \\
\text { each day }\end{array}$ & $\begin{array}{l}\text { Count } \\
\text { \% within Hours of } \\
\text { Study Time }\end{array}$ & & & & \\
\hline $\begin{array}{l}\text { 3-4 hours } \\
\text { each day }\end{array}$ & $\begin{array}{l}\text { Count } \\
\% \text { within Hours of } \\
\text { Study Time }\end{array}$ & $\begin{array}{l}36 \\
69.2 \%\end{array}$ & $\begin{array}{l}10 \\
19.2 \%\end{array}$ & $\begin{array}{l}6 \\
11.5 \%\end{array}$ & $\begin{array}{l}52 \\
100.0 \%\end{array}$ \\
\hline Total & $\begin{array}{l}\text { Count } \\
\text { \% within Hours of } \\
\text { Study Time }\end{array}$ & $\begin{array}{l}70 \\
75.3 \%\end{array}$ & $\begin{array}{l}17 \\
18.3 \%\end{array}$ & $\begin{array}{l}6 \\
6.5 \%\end{array}$ & $\begin{array}{l}93 \\
100.0 \%\end{array}$ \\
\hline
\end{tabular}

In addition, the regularity of studying, which was expected to be an important factor for student success, did not have any significant relationship with the students' GPA ( $p>.05)$.

Methods of study had a significant relationship with the students' GPA $(p=0.016)$. Doing exercises was considered by these high-achiever students to be the best learning strategy to comprehend the contents of the modules. It is worth noted that $25 \%$ of the students doing the exercises when learning obtained a GPA of $\mathbf{3 . 0 0}$ or higher.

Table 8. The results of cross tabulation between study methods with students' GPA

\begin{tabular}{|c|c|c|c|c|c|}
\hline \multicolumn{6}{|c|}{$[n=93]$} \\
\hline \multicolumn{2}{|l|}{ Methods of Study } & $\begin{array}{l}\text { GPA Categ } \\
2.50-2.99\end{array}$ & $\begin{array}{l}\text { ry } \\
3.00- \\
3.49\end{array}$ & $\begin{array}{l}3.50- \\
4.00\end{array}$ & Total \\
\hline Take Notes & $\begin{array}{l}\text { Count } \\
\% \text { within Methods } \\
\text { of Study }\end{array}$ & $\begin{array}{l}3 \\
33.3 \%\end{array}$ & $\begin{array}{l}4 \\
44.4 \%\end{array}$ & $\begin{array}{l}2 \\
22.2 \%\end{array}$ & $\begin{array}{l}9 \\
100.0 \%\end{array}$ \\
\hline Make Summary & $\begin{array}{l}\text { Count } \\
\% \text { within Methods } \\
\text { of Study }\end{array}$ & $\begin{array}{l}4 \\
100.0 \%\end{array}$ & $\begin{array}{l}0 \\
0.0 \%\end{array}$ & $\begin{array}{l}0 \\
0.0 \%\end{array}$ & $\begin{array}{l}4 \\
100.0 \%\end{array}$ \\
\hline $\begin{array}{l}\text { Do the } \\
\text { Exercises }\end{array}$ & $\begin{array}{l}\text { Count } \\
\% \text { within Methods } \\
\text { of Study }\end{array}$ & $\begin{array}{l}63 \\
79.7 \%\end{array}$ & $\begin{array}{l}12 \\
15.2 \%\end{array}$ & $\begin{array}{l}4 \\
5.1 \%\end{array}$ & $\begin{array}{l}79 \\
100.0 \%\end{array}$ \\
\hline $\begin{array}{l}\text { Look for Other } \\
\text { Resources }\end{array}$ & $\begin{array}{l}\text { Count } \\
\% \text { within Methods } \\
\text { of Study }\end{array}$ & $\begin{array}{l}0 \\
0.0 \%\end{array}$ & $\begin{array}{l}1 \\
100.0 \%\end{array}$ & $\begin{array}{l}0 \\
0.0 \%\end{array}$ & $\begin{array}{l}1 \\
100.0 \%\end{array}$ \\
\hline Total & $\begin{array}{l}\text { Count } \\
\% \text { within Methods } \\
\text { of Study }\end{array}$ & $\begin{array}{l}70 \\
75.3 \%\end{array}$ & $\begin{array}{l}17 \\
18.3 \%\end{array}$ & $\begin{array}{l}6 \\
6.5 \%\end{array}$ & $\begin{array}{l}93 \\
100.0 \%\end{array}$ \\
\hline
\end{tabular}

\section{DISCUSSIONS and CONCLUSION}

High school graduates studying at the UT had the potential to complete their studies successfully, even though research indicated that more than $60 \%$ of students of online learning program already held a degree (Yukselturk \& Bulut, 2007). In addition, the UT's younger students ( $<35$ years old, with the average of 29 years old) also had the potential to complete their studies successfully. This finding was similar to that reported by Vu et al, (2014). They reported that among students of a professional development online training program, $71 \%$ of those who completed the program were in the age group of 25-34 years old. The dominant characteristics of high-achiever students in this research can be studied 
more elaborately in subsequent research since the characteristics of adult learners contributed to their intention to participate in learning ( $\mathrm{Ng} \&$ Confessore, 2011).

High-achiever students at UT feel confident to complete their studies at the UT. Their selfconfidence motivates them to study. The intention to improve their work-related competencies seemed to motivate them to study. That is, they had chosen the study program that they thought was relevant to their job. Latif et al. (2016) stated that as learning is usually a voluntary activity, continuing to higher education to improve work skills and professional development is an individual decision. Thus, the student motivation to advance their study to support their job performance and to eran a degree is the driving force for studying. Also, their strong belief that they were able to complete their studies might be the factor that distinguished them from the less successful students. This agrees with findings indicated that self-efficacy is the best predictor for the success of learning in the blended learning system (Lynch \& Dembo, 2004) or an important factor in online instruction (Cho \& Jonassen, 2009).

Unfortunately, this study did not find a significant correlation between student motivation and their GPA. However, by considering the significance value of $p=.084$, there is a possibility that if the number of samples were increased the results could be different. This means that the students' self-efficacy more or less motivated them to be successful, which in turn heightened their intention to study and achieve higher GPAs. For example, interviews with the students indicated that all of the interviewees took the effort to do the formative tests provided in the modules and/or the self-assessment tests provided in the UT's website. Furthermore, all the respondents made summaries of the modules they studied. This learning effort must have some relationship with their strong motivation to be successful.

With regards to learning habits, generally, the respondents liked to study at night and at weekends. This is a logical consequence since most of them worked during the day. However, less successful students might also study at night or at weekends. Thus, there were probably other indicators of learning habits besides time of study that could influence student success. It would be interesting to know whether the students deliberately left their work place late at night to enable them to use the working facilities for studying, for example, to participate in the online tutorials. Also, for students who chose to study at weekends, was it possible that they spent the whole weekend on studying as most of them took 6-8 courses per semester? Further study needs to investigate what factors enabled these students to set aside time for studying and what kinds of activity they actually did while studying.

Regarding the duration of study time, the findings of this study indicates that many of UT students did not have daily learning habits. It was reported that UT students did not have learning habits that support independent learning (Julaeha, 2002; Nugraheni \& Pangaribuan, 2006). In 2002, Julaeha reported that the majority of UT students $(62 \%)$ who responded to her study did not learn regularly. Nonetheless, with regard to the hours of study, UT students still did not spend enough time studying. Around one third of the respondents in Julaeha's study in 2002 were reported to study 1-2 hours per day whereas $56 \%$ of the respondents of this study reported that they studied 3-4 hours per day. In comparison, the successful participants of an online professional development program took part in the online instruction for 4-5 hours on average whereas the unsuccessful participants attended the online instructional program for around 2 hours (Vu et al, 2014). As well, in another study involving students in the University of South Africa (UNISA), it was reported that successful students studied more than twice the time of study (286 hours per year) of those who were failing (124 hours per year) (Risenga, 2010). This suggests that considering ODL students usually are workers, they need to be guided to plan and manage their time to balance the time spent for doing job related responsibilities and studying. 
In addition, the results of this study indicate that students who had lower GPA spent less hours for studying. There was no student who studied more than 4 (four) hours a day for one course. It could be interesting to study further whether these high-achiever students did or never did cram for an examination the night before. Eventhough it is disappointing that the hours of study time had no significant relationship with the students' GPAs, considering that the significance level of the relationship was close enough to the alpha of $0.05(p=.069)$, further studies should increase the sample size to see whether the results would be different.

Besides the length of study time dedicated to doing the assignments, the quality of time used for learning also influences the result of one's learning (Romero \& Barbera, 2012). The motivation to learn will direct students to manage their time so that they can set aside some time for studying. According to Romero and Barbera Lambropoulos ((2011), the advantage of regular universities is that they can encourage students to study at a certain time by forcing them to be present in class. In the ODL system, however, the students themselves had to manage their study time. The ability to self-regulate one's own learning was reported to contribute to the students' success in learning (Pintritch \& DeGroot, 1990). Students who set their own learning objectives and can self-regulate their learning are more likely to succeed in their studies than those who cannot (Zimmerman, 2002; Azevedo, Guthrie, \& Seibert, 2004).

The finding indicates that high-achiever students at the UT did not have a clear pattern of study time. Some students studied every day and some studied every weekend. Some students who had the highest GPAs (3.50-4.00) also did not have a regular/routine schedule for studying. Nonetheless, the findings indicated that these successful students thought that doing the assignments helped them learn the course materials. Further study could investigate whether these high-achiever students do not need a fixed schedule to study because they believe that they can study whenever they have spare time or have other reasons. Also, the next study could investigate how much time the higher achiever students actually study the learning materials and how much time spent on doing the assignments. It would be interesting to learn how students who have limited time to study and did not have a regular, daily study time can be successful in their study at UT.

A poorer study habit of ODL students was also reported by Singh et al. (2012). Students in ODL learning environment in India were found to have significantly poorer study habits than students in the traditional learning environment. According to Singh et al., ODL students usually learnt driven by their intrinsic motivation to earn a degree or advance their job related skills. Thus, passing an examination was very important for them, while having regular study time was less important than having time devoted for family, social and job related responsibilities. On the other hand, students in the regular universities were having better study habits due more to the extrinsic motivation, such as the present of the teacher which implement immediate reward and punishment. Also, the academic performance of students in the regular universities was easily scrutinized by their parents and peers, which may motivate them to study more to achieve better. Nonetheless, aside from the help from tutors and staff, the ODL institutions may be able to improve the impact of external motivation to improve the students study habits by providing course materials and learning experiences that relate to their needs to enhance their professional development (Baxter, 2012).

One of the limitations of this study was the small number of the sample $(n=93)$, which did not represent students from all schools and ROs. The small sample size was particularly due to the small number of students who responded to the email of invitation to participate in this research. Inaccurate student email addresses documented in the SRS and unwillingness to participate in the study could have been their reasons for not responding. In addition, due to the limited time available the interview could only be conducted with students residing in Bogor. Interviews using the telephone were also not possible because the students' telephone numbers, especially their cellular phone numbers, available in the SRS, have not been updated. Many students did not update their phone number probably 
because they can communicate with the university with other means, such as via emails, contact center, a student representative as a liaison person, or coming in person to the Regional Office. Nonetheless, UT needs to remind its students to report their new phone number when they change their number in order for the university to easily distribute information or reminders to students.

Considering the higher number of student withdrawals in any ODL institution compared to conventional universities, UT need to study the characteristics, student motivation, learning habits and also the learning strategies of the students who are successful in studying in this system. The institution must also learn which variable(s) could be the most important factor(s) for the student achievement. The findings of this study can be used for further study to develop a model of the learning strategies and habits that might help to improve the achievement of less successful students in ODL system.

In general, the successful students considered that doing assignments helped them to comprehend the learning materials. Time of study also had a significant relationship with the students' GPA. Likewise, the hours of study time had the potential to contribute to the GPA. Based on the findings of the study, ODL institutions need to encourage and motivate the less successful students so that they believe in themselves and feel that they are able to complete their study. These students need to be encouraged to always use their spare time for studying. They need to be informed about the learning habits that have successfully contributed to the success of other students in completing their study, such as doing self-assessments and preparing well for examinations. The self-assessment might be one of the important factors that contributed to the successful students' GPAs. By doing the self-assessment tests, the student could learn the characteristics of the examination questions at the UT so that they could determine specific learning strategies accordingly.

To conclude, ODL institutions such as UT should consider the importance of providing training in student motivation, learning habits as well as learning strategies for new students in order to support their studies at this learning environment. As importantly, UT need to provide a gudance system in which students can learn how to plan and follow their study time by balancing their time for doing work and family related responsibilities and studying. In addition, the syllabus of each course must provide an expected duration of time of study to complete each course unit so that students can allocate their time to complete the course.

ACKNOWLEDGEMENTS: This paper was written based on a research study funded by Universitas Terbuka in 2014, Indonesia titled "The characteristics and learning habits of successful students of Universitas Terbuka".

\section{BIODATA and CONTACT ADDRESSES of AUTHORS}

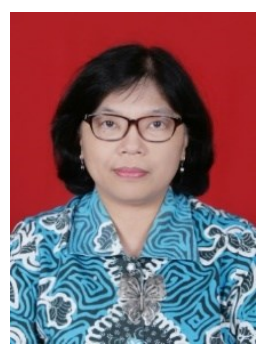

Kristanti Ambar PUSPITASARI is an Associate Professor at Universitas Terbuka, Fakultas Keguruan dan Ilmu Pendidikan (Faculty of Education), Universitas Terbuka. Dr. Kristanti gained her Ph.D. in Instructional Systems at Florida State University in June 2012. Her research interest areas are open and distance learning, e-learning, self-regulated learning, student support, student assessment, and student success. She has published some book chapters and other national and international articles, papers submitted to international meetings.

Kristanti Ambar PUSPITASARI

Fakultas Keguruan dan Ilmu Pendidikan

Universitas Terbuka, 15418, Tangerang Selatan, Indonesia

Phone: +6281511515678,

E-mail: ita@ecampus.ut.ac.id 


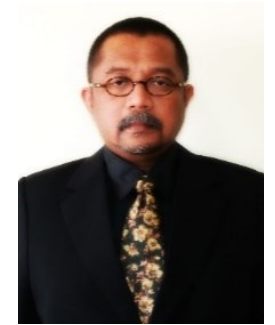

Boedhi OETOYO is a lecturer at Universitas Terbuka, Fakultas Hukum, IImu Sosial, dan Ilmu Politik (Faculty of Law, Social and Political Sciences), Universitas Terbuka. Mr. Boedhi gained his Master of Arts in Interdisciplinary Studies at University of Victoria in 1995. His research interest areas are student success, student support, social problems, ethics, social philosophy. He has published some national articles and papers submitted to international meetings.

\section{Boedhi OETOYO}

Fakultas Hukum, IImu Sosial, dan Ilmu Politik

Universitas Terbuka, 15418, Tangerang Selatan, Indonesia

Phone: +628161819624,

E-mail: boedhi@ecampus.ut.ac.id

\section{REFERENCES}

Aragon, S., \& Johnson, E. (2008). Factors influencing completion and noncompletion of community college online courses. American Journal of Distance Education, 22(3), 146-158. doi: 10.1080/08923640802239962

Azevedo, R., Guthrie, J. T., \& Seibert, D. (2004). The role of self-regulated learning in fostering students' conceptual understanding of complex systems with hypermedia. Journal of Educational Computing Research, 30(1 \& 2), 87-111.

Baxter, J. (2012). Who I am and what keeps me going? Profiling the distance learning student in higher education. IRRODL, 13(4). 107-129.

Cho, M-H., \& Jonassen, D. (2009). Development of the human interaction dimension of the Self-Regulated Learning Questionnaire in asynchronous online learning environments. Educational Psychology, 29(1), 117-138.

Doherty, W. (2006). An analysis of multiple factors affecting retention in Web-based community college courses. The Internet and Higher Education, 9(4), 245-255. doi: 10.1016/j.iheduc.2006.08.004

Fozdar, B. I., Kumar, L. S., \& Kannan, S. (2006). A survey of a study on the reasons responsible for student dropout from the Bachelor of Science Programme at Indira Gandhi National Open University. International Review of Research in Open and Distance Learning, 7(3), 1-15.

Holder, B. (2007). An investigation of hope, academics, environment, and motivation as predictors of persistence in higher education online programs. The Internet and Higher Education, 10(4), 245-260. doi: 10.1016/j.iheduc.2007.08.002

Latif, L.A.; Subramaniam, T.T.; Khatab, Z.A. Learner profiling towards improving learner success. International Conference on Open and Flexible Education (ICOFE), 6-8 July 2016, Hongkong.

Julaeha, S. (2002). Memahami gaya dan strategi belajar mahasiswa (Understanding students' learning style and strategy). Jurnal Pendidikan Terbuka dan Jarak Jauh, 3(2).

Lynch, R., \& Dembo, M. H. (2004). The relationship between self-regulation and online learning in a blended learning context. International Review of Research in Open and Distance Learning, 5(2), 1-16.

McGivney, V. (2004). Understanding persistence in adult learning. Open Learning, 19(1), 33-46. doi: 10.1080/0268051042000177836.

Ng, S.F., \& Confessore, G.J. (2011). Assessing the capacity for success of distance learning student in Malaysia. Procedia Social and Behavioral Sciences, 15, 1742-1750. 
Nugraheni, E., \& Pangaribuan, N. (2006). Gaya belajar dan strategi belajar mahasiswa jarak jauh: Kasus di Universitas Terbuka (Learning style and strategy of distance education students: A case of Universitas Terbuka). Jurnal Pendidikan Terbuka dan Jarak Jauh, 7(1), 68-82.

Pintrich, P. R., \& DeGroot, E. V. (1990). Motivational and self-regulated learning components of classroom academic performance. Journal of Educational Psychology, 82(1), 33-40.

Risenga, A. (2010). Attributes of students' success and failure in typical ODL institutions.

Progressio 32 (2), 85-101.

Roblyer, M. D. (1999). Is choice important in distance learning: A study of student motives for taking Internet-based courses at the high school and community college levels. Journal of Research in Computing Education, 32(1), 157-171.

Romero, M., \& Barbera, E. (2011). Quality of learners' time and learning performance beyond quantitative time-on-task. IRRODL, 12(5), 125-137.

Singh, S.; Singh, A.; Singh, K. (2012). Motivation Levels among Traditional and Open Learning Undergraduate Students in India. IRRODL, 13(3), 19-40.

Schunk, D. H. (1991). Self-efficacy and academic motivation. Educational Psychologist, 26(3 \& 4): 207-231.

Vu, P., Cao, V., Vu, L., \& Cepero, J. (2014). Factors driving learner success in Online Professional Development. IRRODL, 15(3), 120-139.

Wilson, J. (1997). Self-regulated learners and distance education theory. Occational Papers in Educational Technology, June Retrieved from http://www.usask.ca/education/coursework/802papers/wilson/wilson.html

Yukselturk, E. \& Bulut, S. (2007). Predictors for student success in an online course. Educational Technology \& Society, 10 (2), 71-83.

Zimmerman, B. J. (2002). Becoming a self-regulated learner: An overview. Theory into Practice, 41(2), 64-70. 